\title{
Intercostal hemangioma of the chest wall
}

\author{
Anton Dzian, Julian Hamzík \\ Clinic of Thoracic Surgery, Jessenius Faculty of Medicine in Martin, Comenius University, Martin, Slovakia
}

Kardiochirurgia i Torakochirurgia Polska 2016; 13 (1): 58-60

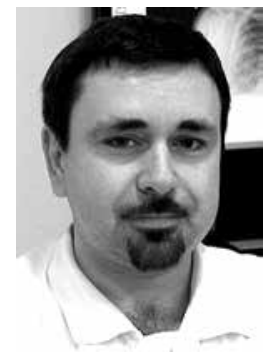

\begin{abstract}
The authors describe a case of a 36-year-old patient who had six months' pain of the thoracic spine and left chest. A soft slowly growing resistance was present on the dorso-lateral side of the left chest wall, in the range of the seventh to ninth rib. According to the medical history, the patient did not have any prior trauma and malignancy. A well-defined tumor of the left chest wall with calcifications, which grew to the seventh and eighth intercostal space, was present on computed tomography (CT) and magnetic resonance (MR) scans. The patient underwent resection of the tumor with the chest wall and reconstruction with polypropylene mesh. Histologically, it was a venous hemangioma, one of very rare tumors of the chest wall.
\end{abstract}

Key words: chest wall tumor, venous hemangioma, chest wall resection.

\section{Introduction}

Vascular tumors affecting the chest wall are very rare. The literature suggests sporadic case reports of chest wall hemangiomas. Hemangioma is defined as a neoplastic entity, which arises from blood vessels. Histologically it can be categorized as one of five histologic subtypes: capillary, cavernous, venous, arteriovenous or mixed [1]. Case reports describe hemangiomas of the chest wall arising from intercostal muscles (intramuscular, intercostal) or from the medullary canal of the rib (bone hemangioma). Intercostal hemangiomas account for approximately $0.01 \%$ of all benign hemangiomas [2]. We describe a patient with an intercostal venous hemangioma presenting as a chest wall tumor, for which resection of the chest wall was successfully accomplished.

\section{Case report}

A 36-year-old male was admitted to the Clinic of Thoracic Surgery for a slowly progressing chest mass and six-month pain of the thoracic spine and left chest. There was no medical history of trauma of the chest wall and no oncological

\section{Streszczenie}

Autorzy przedstawiają przypadek 36-letniego pacjenta, który zgłosił odczuwanie bólu w piersiowym odcinku kręgosłupa i lewej stronie klatki piersiowej przez 6 miesięcy. Pomiędzy siódmym a dziewiątym żebrem na tylno-bocznej ścianie klatki piersiowej stwierdzono wyczuwalny, powoli rosnący, miękki opór. Według informacji z wywiadu pacjent nie doznał wcześniej urazu ani nie cierpiał na chorobę złośliwą. Badania tomografem komputerowym i rezonansem magnetycznym zwizualizowały wyraźnie odgraniczony, sięgający siódmej i ósmej przestrzeni międzyżebrowej guz lewej ściany klatki piersiowej ze zwapnieniami. Guz został poddany resekcji, a ścianę klatki piersiowej zrekonstruowano za pomocą siatki polipropylenowej. Histologicznie guz okazał się żylnym naczyniakiem, jednym z bardzo rzadkich guzów ściany klatki piersiowej.

Słowa kluczowe: guz ściany klatki piersiowej, naczyniak, resekcja ściany klatki piersiowej.

disease. During clinical examination a slowly growing soft resistance located dorso-laterally in the range of the seventh to ninth rib on the left chest was found. Chest roentgenogram showed a left lateral soft-tissue mass of the chest wall. Chest magnetic resonance (MR) imaging showed a wellbordered tumor of the left chest wall, with a size of $9.5 \mathrm{x}$ $9 \times 3 \mathrm{~cm}$ with calcifications, overgrowing to the seventh and eighth intercostal space (Fig. 1). According to the result of MR, hemangioma was suspected. The patient underwent surgery. A complete resection of the tumor with the left seventh, eighth and ninth ribs and their intercostal muscles was successfully accomplished (Fig. 2B). Blood loss was up to $500 \mathrm{ml}$. Reconstruction of the chest wall was achieved using polypropylene mesh (Fig. 2A). Microscopically, structures of benign vascular lesions corresponding to intramuscular venous hemangioma with numerous phleboliths were found in adipose tissue and striped muscle in the resected chest wall. The surgical margins were negative for tumor structures. The patient was discharged on the seventh postoperative day, and presently, ten months after the operation, he is doing well, without any evidence of local recurrence. 

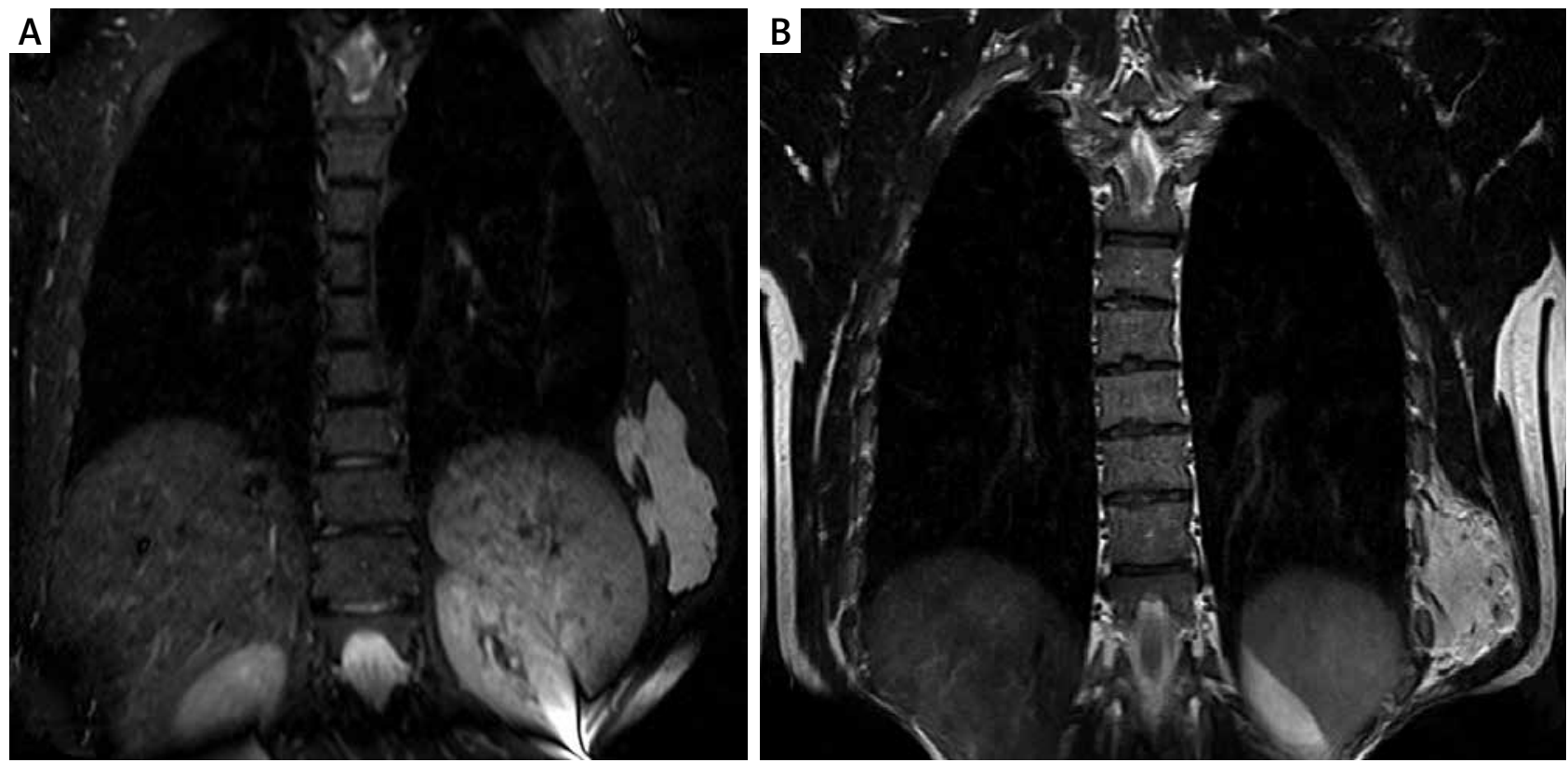

Fig. 1. Coronal T2-weighted MR images of the intercostal hemangioma of the chest wall (A) and enhancement by contrast media (B)
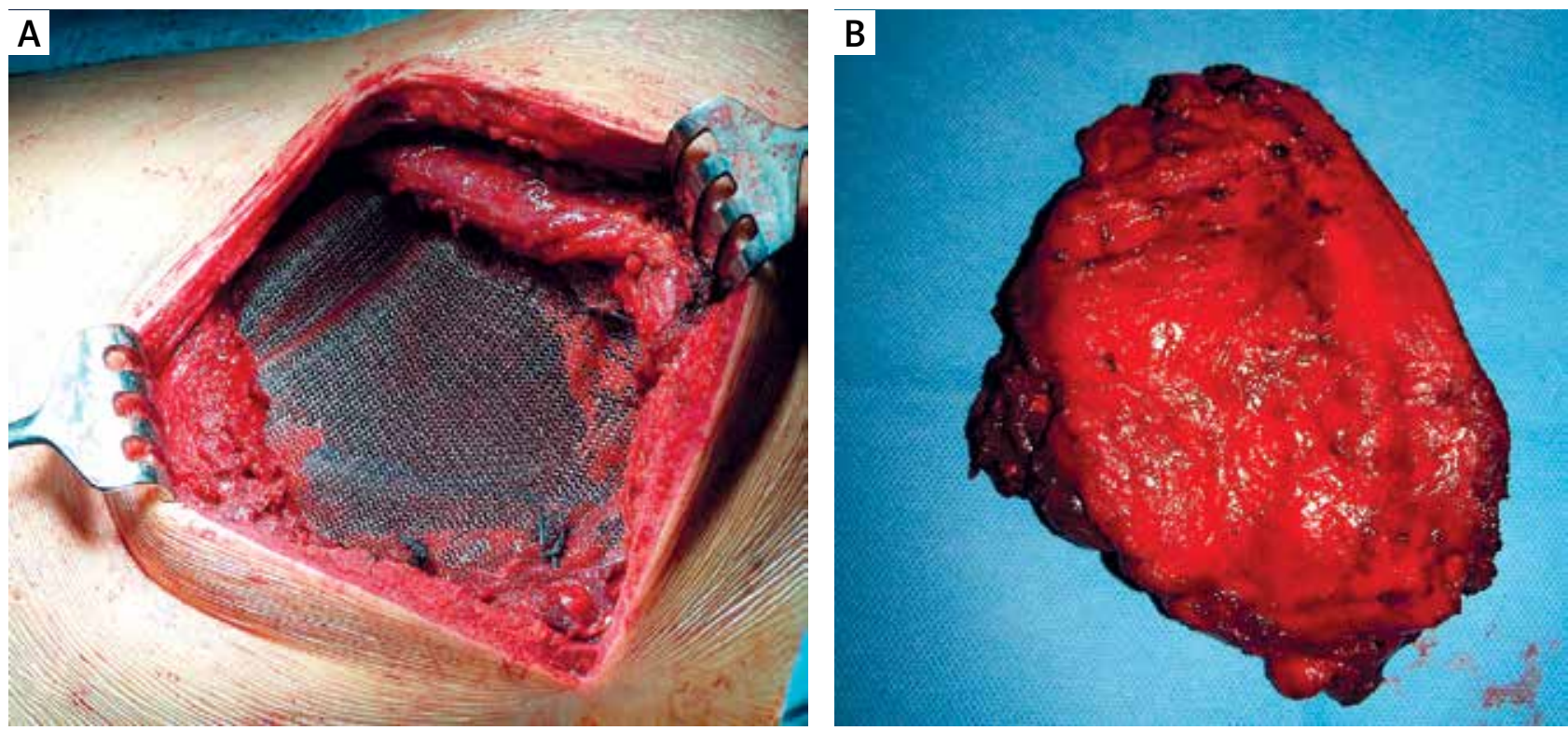

Fig. 2. Reconstruction of the chest wall with used polypropylene mesh (A). Macroscopic appearance of the resected tumor with chest wall (B)

\section{Discussion}

Intramuscular hemangiomas occur most often in people under 30 years of age and show no sex predilection. Generally they are considered to be congenital, but factors such as chest trauma or repetitive bruises may play a role in development of intramuscular hemangioma [2, 3]. Patients with intercostal hemangioma clinically may present with palpable mass of the thoracic wall, soft-tissue bulging, pain or a combination of these signs and symptoms. Intercostal hemangioma should be included in the differential diagnosis of primary soft tissue chest wall tumors, such as fibromas, lipomas, giant cell tumors, neurogenic tumors, desmoids, soft tissue sarcomas, connective tissue tumors and metastatic tumors. Conventional radiography hemangiomas may be seen as an ill-defined soft-tissue mass. Phleboliths are specific to hemangiomas and helpful in diagnosing soft-tissue hemangioma [4]. Regional ribs may show periostitis, trabecular coarsening and cortical changes such as thickening, thinning or erosion [5].

Computed tomography (CT) of the chest localizes and characterizes chest wall hemangioma, its effect on adjacent structures and it can also reveal phleboliths. A preliminary diagnosis may be established by MR examination, when classic MR findings are present: tumor mass of low 
or intermediate signal intensity in T1-weighted images and a high signal intensity in T2-weighted images (vascularity is manifested as a high signal intensity) [4]. Invasive diagnostic techniques, such as open or percutaneous (CT-guided or echo-guided) needle biopsy are also available, but needle biopsy of hemangioma may cause bleeding. In the case of big hemangiomas, a preoperative embolization of hemangiomas with the aim to minimize the risk of intraoperative complications like excessive bleeding, is necessary before surgery. Intercostal hemangiomas are managed by complete surgical chest wall resection with clean surgical margins. The next decision about skeletal reconstruction depends on the size and location of the defect. Large chest wall defects $(>5 \mathrm{~cm}$ ) require skeletal reconstruction. Posterior defects that lie above the fourth rib and are covered by the scapula do not need to be reconstructed. The choice of synthetic prosthetic material depends on the location of the defect, its size and surgeon's preference and experience.

In conclusion, this case represents a very rare intercos- tal hemangioma of the chest wall. Presumptive diagnosis was based on $M R$, resection was performed for definitive diagnosis and treatment.

\section{Disclosure}

Authors report no conflict of interest.

\section{References}

1. Murphey MD, Fairbairn KJ, Parman LM, Baxter KG, Parsa MB, Smith WS. Musculoskeletal angiomatous lesions: radiologic-pathologic correlation. Radiographics 1995; 15: 893-917.

2. Scott JE. Haemangioma in skeletal muscle. Br J Surg 1957; 44: 496-501.

3. Shimizu K, Yamashita Y, Hihara J, Seto Y, Toge T. Cavernous hemangioma of the rib. Ann Thorac Surg 2002; 74: 932-934.

4. Ly JQ, Sanders TG. Case 65: hemangioma of the chest wall. Radiology 2003; 229: 726-729.

5. Sung MS, Kang HS, Lee HG. Regional bone changes in deep soft tissue hemangiomas: radiographic and MR features. Skeletal Radiol 1998; 27: 205-210. 